\title{
The Challenges of the Mexican Intermediated Securities Holding System and Opportunities for Modernization
}

Abstract .94

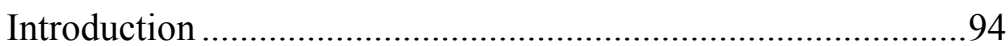

I. Mexico's Securities Holding Framework ........................96

A. Legal Infrastructure ..............................................96

B. Configuration of the Intermediated System ...........100

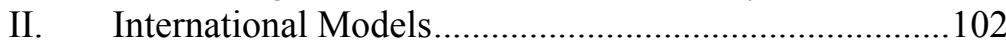

III. The Process of Immobilization of Securities in Mexico and the Types of Securities Accounts ...........................106

A. Immobilization Steps and Rights Arising Therefrom

B. Moving Down the Holding Tiers ...........................110

IV. The Foundations of the Mexican Intermediated Securities System

V. Pledge of Securities: Financial Pledge of Intermediated Securities

A. Law Applicable to Pledges of Intermediated

Securities

B. Pre- and Post-default Rights of the Secured Creditor

\footnotetext{
* Marek Dubovec is the Executive Director of NatLaw and part-time Professor of Practice at the James E. Rogers College of Law, the University of Arizona.

Adalberto Elias is a Supervising Research Attorney at NatLaw.

We are grateful for the valuable comments and suggestions made by Professor Charles W. Mooney Jr. (University of Pennsylvania Law School), Professor Boris Kozolchyk (University of Arizona, James E. Rogers College of Law), Neale Bergman (International Institute for the Unification of Private Law (UNIDROIT)), Dr. Renata Herrerías Franco (Instituto Tecnológico Autónomo de México), Yamil Patiño Muñoz (S.D. Instituto para el Depósito de Valores (INDEVAL)), Lic. Gerardo Cruz Balderas (Universidad Anáhuac México), and Professor Francisco Garcimartín (Universidad Autónoma de Madrid).
} 
VI. Final Remarks 129

\begin{abstract}
This Article examines the legal institutions and doctrines underlying the current intermediated system for the holding of securities in Mexico. Rather than revamping the legal framework governing intermediated securities, Mexico's legislature enacted several incremental changes in an attempt to align the framework with the practices and norms of the twenty-first century. These modifications were introduced without any coherent and consistent policy justifications, resulting in a framework inhospitable to transactions with intermediated securities, especially secured loans. This framework also has many gaps, such as in the area of conflict of laws, which makes it unsuitable for foreign investors. Given the recent successful efforts to modernize Mexico's secured transactions law and the filing system, as well as the ongoing digitization of the warehouse receipts system using distributed ledger technologies (Blockchain), it is surprising that very little attention has been paid to modernizing the intermediated securities system. In its future modernization efforts, Mexico should seriously consider the recommendations of the UNIDROIT Legislative Guide on Intermediated Securities, adopted in May 2017, to align with the best international standards. The Legislative Guide is based on the principles underlying the U.S. Uniform Commercial Code Article 8, which would make the Mexican securities market more attractive for U.S. investors and lenders.
\end{abstract}

\title{
INTRODUCTION
}

Today, securities in developed and developing economies are regularly held through intermediaries that maintain securities accounts for their customers. This holding system is faster, safer, more efficient, and operationally certain. ${ }^{1}$ However, it also generates a number of new risks, such as a failure or collapse of the intermediary and a lack of sufficient securities to satisfy the claims of customers and secured creditors - the intermediary risk. ${ }^{2}$ This holding pattern, which has become the norm for securities traded on exchanges, is increasingly

1 HideKi Kanda ET AL., OFFICIAL COMMENTARY ON THE UNIDROIT CONVENTION ON SUBSTANTIVE RULES FOR INTERMEDIATED SECURITIES ๆ Int-2 (2012).

2 Steven L. Schwarcz \& Joanna Benjamin, Intermediary Risk in the Indirect Holding System for Securities, 12 DuKE J. COMP. \& INT'L L. 309, 309 (2002). 
utilized for securities traded in over-the-counter markets, including those with much less liquidity (e.g., interests or participations in partnerships). In some systems, the only condition for holding an asset in a securities account with an intermediary is whether the asset is capable of being credited to that securities account. ${ }^{3}$ Nonetheless, the emergence of intermediated holding systems has not completely eliminated direct holding for securities where, for instance, an investor is registered as a shareholder on the books of the issuer or is in possession of a bond issued in the form of a bearer certificate. ${ }^{4}$ These two holding systems do not only co-exist, they also interact with one another, allowing investors to switch between them. ${ }^{5}$ Accordingly, an investor may request its intermediary to cancel a credit entry in their securities account and deliver a security certificate if such a transformation is authorized by the terms of the security. The investor may also deposit its bearer certificate with an intermediary and receive a credit entry corresponding to such deposit in its securities account.

This Article examines the legal institutions and doctrines underlying the current intermediated system for the holding of securities ("intermediated system") in Mexico. Although the focal point of this Article is the intermediated securities holding system, a proper understanding of the conceptual and functional legal bases of the direct holding system is essential to fully understand the Mexican intermediated system. ${ }^{6}$ For that reason, we illustrate some of the doctrinal barriers encountered by the designers of the framework regulating the intermediated system and how those barriers were addressed, or kept intact, in an attempt to satisfy the needs of the marketplace. That analysis uncovers a number of inefficiencies caused by applying traditional concepts (e.g., a pledge) and their requisite formalities to modern day transactions, thus unnecessarily increasing

\footnotetext{
3 See U.C.C. § 8-102(9)(iii) (AM. LAW InST. \& UNIF. LAW COMM’N 1994) which provides that a financial asset includes "any property that is held by a securities intermediary for another person in a securities account if the securities intermediary has expressly agreed with the other person that the property is to be treated as a financial asset under this Article."

4 Parts 2-4 of U.C.C. Article 8 apply to directly held securities. Part 2 of U.C.C. Article 8 deals with the issuance and the issuer of securities. Part 3 of U.C.C. Article 8 covers the transfer of certificated and uncertificated securities. Part 4 of U.C.C. Article 8 addresses registration of securities.

5 Marek Dubovec, The Law of Securities, Commodities and Bank Accounts 40-41 (2014).

6 For more information on the direct holding system in Mexico, see RAÚL CERVANTES AhumAdA, Títulos Y OPERACIONES DE CRÉDITO [Credit Instruments and Operations] (Manuel Porrúa ed., 2007).
} 
the cost of utilizing securities credited to accounts maintained by intermediaries ("intermediated securities") as collateral and impeding market liquidity. As presently constituted, the framework for intermediated securities lacks any coherent and consistent policy justifications for its various components, such as the requirements for enforcing a financial pledge after default. We argue that, for the most part, the inefficiencies may be attributed to the attempt to provide a legal framework that attempts to adapt traditional legal concepts, rather than looking to models, such as those developed by the International Institute for the Unification of Private Law (UNIDROIT), that specifically deal with intermediated securities.

\section{I}

\section{MEXICO’S SECURITIES HOLDING FRAMEWORK}

\section{A. Legal Infrastructure}

Mexico has two systems for the holding of securitiesintermediated and direct. The legal framework for the direct holding system has been in place since 1934, and is formed mainly by: (1) the General Law for Securities and Credit Operations (Ley General de Títulos y Operaciones de Crédito), ${ }^{7}$ and (2) the General Law for Commercial Corporations (Ley General de Sociedades Mercantiles). ${ }^{8}$ The intermediated system was implemented with the enactment of the Stock Market Law of 1975, Ley del Mercado de Valores, (1975 LMV), ${ }^{9}$ which was replaced in 2005 by a new Stock Market Law (2005 LMV), ${ }^{10}$ but the underlying legal concepts and principles were not substantially changed. The 2005 LMV is not the sole legal source governing intermediated securities as the following laws continue to apply subsidiarily: (1) commercial laws, including the Commercial Code (Código de Comercio), ${ }^{11}$ the General Law of Securities and

\footnotetext{
7 Ley General de Títulos y Operaciones de Crédito [LGTOC] [General Law for Securities and Credit Operations], as amended, Diario Oficial de la Federación [DOF], 27-8-1932 (Mex.) [hereinafter LGTOC].

8 Ley General de Sociedades Mercantiles [LGSM] [General Law of Commercial Corporations], as amended, Diario Oficial de la Federación [DOF], 4-8-1934 (Mex.) [hereinafter LGSM].

9 Ley del Mercado de Valores [LMV] [Stock Market Law], as amended, Diario Oficial de la Federación [DOF], 2-1-1975, repealed by Decree DOF 30-12-2005 (Mex.) [hereinafter 1975 LMV].

10 Ley del Mercado de Valores [LMV] [Stock Market Law], as amended, Diario Oficial de la Federación [DOF], 30-12-2015 (Mex.) [hereinafter 2005 LMV].

11 Código de Comercio [CCom] [Commercial Code], as amended, Diario Oficial de la Federación [DOF], 4-7-2016 (Mex.) [hereinafter Commercial Code].
} 
Credit Operations, and the General Law of Commercial Corporations (Ley General de Sociedades Mercantiles); (2) financial and commercial usages; and (3) the Federal Civil Code (Código Civil Federal). ${ }^{12}$ Other laws that regulate some aspects of the intermediated holding system are the Law of the Mexican Central Bank (Ley del Banco de México) ${ }^{13}$ and the Payments Systems Law (Ley de Systemas de Pagos $).{ }^{14}$ The relationship between the intermediated system and the central securities depository, Institute for the Deposit of Securities (Instituto para el Depósito de Valores) ("Indeval"), is largely governed by Indeval's Internal Regulations ${ }^{15}$ and Internal Operations Manuals-primarily the "Deposit, Custody, Administration of Securities and Other Services Operations Manual" (Manual Operativo de Depósito, Custodia, Administración de Valores y Otros Servicios),${ }^{16}$ and the Operations Manual of Services for the Fulfillment of Depositors' Obligations (Manual Operativo de Servicios Para el Cumplimiento de las Obligaciones de los Depositantes). ${ }^{17}$ Regulations, such as those issued by the National Banking and Securities Commission (Comisión Nacional Bancaria y de Valores), also govern some aspects of the intermediated system.

12 Código Civil Federal [CC] [Federal Civil Code], as amended, arts. 754-55, Diario Oficial de la Federación [DOF], 24-12-2013 (Mex.) [hereinafter Civil Code].

13 Ley del Banco de México [LBM] [Mexican Bank Law], as amended, Diario Oficial de la Federación [DOF], 23-12-1993 (Mex.) [hereinafter LBM].

14 BANCO de MÉXICO, El MERCADO DE VALORES GUBERnAMENTALES EN MÉXICO 161 (2014), http://educa.banxico.org.mx/ebooks_descargas/\%7BCD2C4B20-74C9-6BE6-14 CA-CAD02563FED9\%7D.pdf [hereinafter BANCO DE MÉXICO]. See also Ley del Sistemas de Pagos [LSP] [Payment Systems Law], Diario Oficial de la Federación [DOF], 12-122002 (Mex.) [hereinafter PSL].

15 REGLAMENTO INTERIOR DE INDEVAL [INDEVAL INTERNAL REGULATIONS], INDEVAL, http://www.indeval.com.mx/wb3/work/sites/indeval/resources/LocalContent/8 23/7/RGL JUR_Reglamento_Interior_Indeval.pdf (last visited Aug. 20, 2017) [hereinafter INDEVAL INTERNAL REGULATIONS].

16 Manual Operativo de Depósito, Custodia, Administración DE VAlores y Otros Servicios [DEPOSIT, CuStody, Administration OF SECURITIES AND Other SERVICES OPERATIONS MANUAL], INDEVAL, art. 3.06.00 (May 2016), http://www.indeval .com.mx/wb3/work/sites/indeval/resources/LocalContent/1339/4/160524_MOP_JUR_MO DCAVOS_compulsa2016.pdf [hereinafter RULES ON DEPOSIT].

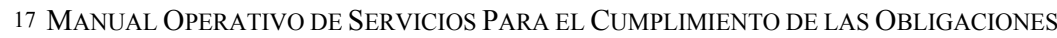
DE LOS DEPOSITANTES [OPERATIONS MANUAL OF SERVICES FOR THE FULFILLMENT OF DEPOSITORS' OBLIGATIONS], INDEVAL (May 2016), http://www.indeval.com.mxwb3 /work/sites/indeval/resources/LocalContent/1339/4/160524_MOP_JUR_MOSCOD_comp ulsa2016.pdf [hereinafter OPERATIONS MANUAL OF SERVICES FOR THE FULFILLMENT OF DEPOSITORS' OBLIGATIONS]. 
As will be shown below, the Mexican legal framework governing the intermediated system remains based on the traditional concepts and legal institutions designed for physical/certificated securitiesincluding negotiability, which presupposes endorsement and delivery of possession (endoso y entrega), the commercial agency contract (comisión mercantil), deposit (depósito), the possessory pledge (prenda), and a special type of endorsement known as "endorsement for administration purposes" (endoso en administración). For instance, the framework governing the Mexican intermediated system attempts to reconcile what is known as the "general legal doctrine of securities" (teoría general de títulos de crédito) with a new and more efficient method for holding and transferring rights in intermediated securities. ${ }^{18}$ This legal doctrine is mainly based on the "reification principle," which provides that "the underlying rights are reified in the paper." 19 In other words, incorporating an intangible right into a document or instrument would make it enforceable strictly on its terms and conditions. Such a design is not surprising, considering that the general Mexican commercial law doctrines and institutions in place at the time the system was developed were designed for a world in which technology, as we know it today, did not exist. ${ }^{20}$ But how negotiation, as understood in the historical context of the Mexican legal system, can be properly applied to transfers of intermediated securities is unclear and uncertain. Gradually, with the proliferation of e-technologies and their implementation within securities holding systems, some of the Mexican commercial law doctrines and institutions had to be adapted in order to provide a solid underpinning for the system of today. However, that has not been the case for all aspects of the Mexican intermediated system, particularly the pledging of intermediated securities. For intermediated securities, the requirements to constitute a pledge were replicated rather than adapted to the intermediated system without taking into account the nature of intermediated securities (as contrasted with assets traditionally pledged, such as artwork), as well as the marketplace in which the securities are transferred. Additional challenges may arise in the adaptation of the

\footnotetext{
18 This doctrine will be further explained below. See infra note 117.

19 Id. See also James S. Rogers, The End OF Negotiable InStruments: Bringing PAYMENT SySTEMS LAW OUT OF THE PAST 45, 51-52 (2001).

20 Victor M. CASTRILlON y Luna, El DeRECho MERCANTIl ANTE Los RETOS DE LA Globalización [MERCANTIle LAW Before the Challenges of Globalization] 301-10, https://archivos.juridicas.unam.mx/www/bjv/libros/5/2332/21.pdf (last visited Aug. 20, 2017).
} 
legal doctrines to e-technologies, such as blockchain, ${ }^{21}$ that Mexico is already considering for its future electronic warehouse receipts system. ${ }^{22}$ Blockchain has the potential to "disintermediate" the clearing and settlement of securities transactions, ${ }^{23}$ further challenging Mexico's current legal framework. ${ }^{24}$ Blockchain also promises to facilitate collateral management through smart contracts that would cause automatic transfer of ownership to securities upon the debtor's default. ${ }^{25}$ While crafting a new legal framework that contemplates the holding of securities directly against the issuer through Blockchain is premature, adoption of a framework that no longer relies on the traditional concepts would be timely. The requirements for the pledging and enforcement of pledges in intermediated securities are especially in dire need of modernization.

Recent efforts to "modernize" the Mexican legal framework governing the intermediated system have curiously been based mainly on the United Nations Commission on International Trade Law's (UNCITRAL) Model Law on Electronic Commerce (1996), as implemented in the Commercial Code, rather than on model rules and best practices specific to intermediated systems. ${ }^{26}$ For instance, these efforts have led to the categorization of the settlement system, administered by the Mexican central securities depository (CSD), as an

21 Eva Micheler, Custody Chains and Asset Values: Why Crypto-securities are Worth Contemplating, 74 C.L.J. 505, 532 (2015) (Eng.); Philipp Paech, Integrating Global Blockchain Securities Settlement with Law and Regulation-Policy Considerations and International Principles, SOCIAL SCIENCE RESEARCH NeTwORK 1 (June 11, 2016), https://papers.ssrn.com/sol3/papers.cfm?abstract_id=2792639.

22 The Mexican Ministry of Economy (Secretaría de Economía) has retained the National Law Center for Inter-American Free Trade ("NatLaw") as a consultant in a project that involves the development of a legislative reform proposal that would enable the issuance, transfer, and collateralization of electronic warehouse receipts in Mexico. See Adalberto Elias, Recent Electronic Warehouse Receipts Developments in Mexico, 33(1) ARIZ. J. INT'L \& COMP. L. 199, 200 (2016).

23 Todd C. Gibson \& Tyler Kirk, Blockchain 101 for Asset Managers, 23 INV. LAW. 1, 4 (2016).

24 See Fin. Indus. Regulatory Auth., Distributed Ledger Technology: IMPLICATIONS OF BLOCKCHAIN FOR THE SECURITIES INDUSTRY 1 (Jan. 2017), http://www .finra.org/sites/default/files/FINRA_Blockchain_Report.pdf. However, the magnitude of the potential disruption on the securities industry remains uncertain.

$25 \mathrm{Id}$. at 5.

26 Oscar Jorge Duran díaz, los Títulos de CRÉdito Electrónicos: Su DESMATERIALIZACIÓN [Electronic Credit Instruments: Their Dematerialization] 164-67 (Manuel Porrúa ed., 2009). 
"information system." 27 Similarly, under the intermediated system, debits and credits to securities accounts are collectively referred to as "data messages," a term adopted literally from the UNCITRAL Model Law on Electronic Commerce. ${ }^{28}$ Thus, instead of addressing the legal uncertainty surrounding transfers of intermediated securities in Mexico, by applying the principle of functional equivalence for electronic records and signatures these efforts only attempt at mere recognition of electronic securities as having the same effect as certificated securities. ${ }^{29}$ E-commerce model legislation is insufficient to provide clear answers to many questions regarding intermediated securities, such as whether the transfer of intermediated securities by book entries to accounts is equivalent to negotiation or novation; whether the transferee of intermediated securities whose account has been credited is equally protected as the holder of a security certificate; how to perfect a pledge over intermediated securities provided as collateral; and so on. Specifically, e-commerce's equivalent functionality principle focuses only on the generic enforceability of electronic messages as if they were sent in paper, and not on the specific rights they may convey.

\section{B. Configuration of the Intermediated System}

The Mexican intermediated securities system is structured as follows: a single CSD (Indeval) at the top, brokerage houses in the middle, and customers and investors at the bottom of the holding chain. ${ }^{30}$ In 2016, the total value of securities deposited at Indeval (including government bonds) was approximately USD $\$ 1.3$ trillion. ${ }^{31}$ There were thirty-six brokerage houses, five of which control seventy-

27 Id. See also U.N. COMM'N ON INT'L TRAdE LAw, UNCITRAL MOdEL LAW ON ElECTRONIC COMMERCE WITH GUIDE TO ENACTMENT 1996 WITH ADDITIONAL ARTIClE 5 BIS AS ADOPTED IN 1998, ART. 2(A), U.N. Sales No. E.99.V.4 (1999), http://www.uncitral .org/pdf/english/texts/electcom/05-89450_Ebook.pdf [hereinafter GUIDE TO ENACTMENT TO THE UNCITRAL MODEL LAW ON ELECTRONIC COMMERCE]. "Information system" means a system for generating, sending, receiving, storing, or otherwise processing data messages. See also Commercial Code, supra note 11, art. 89.

28 See id.

29 Guide to ENACTMENT TO THE UNCITRAL MOdel LAW ON ElECtronic COMMERCE, supra note 27, at 20.

30 Francisco D. Garcimartín, Sistemas de Representación y Tenencia de Valores [Systems of Representation and Holding of Value], ESTUDIO SOBRE LOS SISTEMAS DE REGISTRO, COMPENSACIÓN Y LIQUIDACIÓN DE VALORES EN IBEROAMÉRICA 33 (2012).

31 See Bolsa MeXicana De VALORES, InForme AnNual 2016, at 54, http://www .bmv.com.mx/docs-pub/informeAnual/INFORME\%20ANUAL\%20GRUPO \%20BMV\%2 02016.pdf (last visited Aug. 20, 2017). 
eight percent of the market. ${ }^{32}$ Securities transactions entered into on the securities exchange are cleared through the Central Counterparty of Securities of Mexico S.A. de C.V. (Contraparte Central de Valores de México, S.A. de C.V.) (CCV). ${ }^{33}$ The $\mathrm{CCV}$ is owned by brokerage houses and banks, but is overseen by the central bank and the National Banking and Securities Commission. ${ }^{34}$ Participants in CCV may act as settlement agents or as non-settlement agents who clear their transactions through settlement agents. As of February 2016, the CCV had thirty-two participants, two of which were non-settlement agents. ${ }^{35}$ Trading data is sent to the CCV in real time when trades are executed on the securities exchange. ${ }^{36}$ The $\mathrm{CCV}$ also assesses margin requirements for its participants, which may be posted in the form of cash, government bonds, and other highly rated securities, as well as letters of credit. ${ }^{37}$ In case of a participant's default, the CCV will have access to compensation and reserve funds to cover its losses. ${ }^{38}$

The adequacy of the legal framework governing intermediated securities held through Indeval may be truly tested in the future upon the bankruptcy of one or more significant participants. ${ }^{39}$ Thus far, the 2006 bankruptcy of Abaco Casa de Bolsa, S.A. de C.V., a midsize Mexican brokerage house, was financially insignificant to affect the rights of account holders. ${ }^{40}$

32 Erick Gallardo, 5 Casas de Bolsa que Manejan 78\% de la Inversión de Valores en México [5 Stock Exchange Houses Handle 78\% of the Investment in Securities in Mexico], EL FINANCIERO (Sept. 4, 2016), http://www.elfinanciero.com.mx/empresas/casas-de-bolsa -que-manejan-78-de-la-inversion-de-valores-en-mexico.html.

33 See Evaluación de la Contraparte Central de Valores de MéXico [Evaluation of the Central Securities Counterpart of MeXico], Banco DE MÉXICO (Feb. 2010), http://www.banxico.org.mx/sistemas-de-pago/material-educativo /intermedio/evaluaciones-conforme-a-las-mejores-practicas-inte/sistemas-de-liquidacion -de-valores-y-contrapartes/\%7B11914248-BD80-10CC-C133-81742E016048\%7D.pdf.

34 COMm. On PAyment AND SETtLement Sys., Red BoOK: PAYMEnt, CleARING AND SETTLEMENT SYSTEMS IN MEXICO 254 (2011).

35 See Contraparte Central de Valores de Mexico, S.A. De C.V., Contraparte CENTRAL, http://www.contraparte-central.com.mx/wb3/work/sites/CCV/resources/Local Content/62/9/CCV ALiq y ANoLiq.pdf (last visited Aug. 17, 2017).

36 COMM. ON PAYMENT AND SETTLEMENT SYS., supra note 34, at 273.

37 Id.

38 Id. at 274.

39 Jeanne L. Schroeder, Bitcoin and the Uniform Commercial Code, 24 U. MiAMI BuS. L. REV. 1, 38 (2016). The property law of investment securities becomes critical when a securities intermediary becomes insolvent. $I d$.

40 Resolución mediante la cual se revoca la autorización otorgada a Abaco Grupo Financiero, S.A. de C.V., para constituirse y funcionar como grupo financiero [Resolution 
II

\section{INTERNATIONAL MODELS}

The emergence of intermediated holding for securities challenges the traditional legal framework designed for directly-held securities. The traditional concepts underpinning direct holding systems are insufficient to provide legal certainty to holders of securities evidenced or constituted by credit entries in securities accounts. The Hague Conference on Private International Law adopted the Convention on the Law Applicable to Certain Rights in Respect of Securities Held with an Intermediary ("Hague Securities Convention") in $2006 .{ }^{41}$ This Convention was limited to providing a novel conflict of laws rule based on the "place of the relevant intermediary approach" (PRIMA). ${ }^{42}$ This approach departs from the traditional lex rei sitae approach, under which the law of the place where the securities are located governs the rights thereto. In contrast, the PRIMA approach designates the relevant securities account as the connecting factor. ${ }^{43}$ Under Article 4 of the Hague Securities Convention, the applicable law is the law chosen by the parties in the account agreement, as long as the relevant intermediary, at the time of the agreement, has an office in the country whose law has been chosen. ${ }^{44}$ While this approach is similar to the U.S. Uniform Commercial Code (UCC) sections 8-110 and 9-305, it additionally requires that the relevant intermediary has, at the time of executing an agreement to open a securities account, an office in the jurisdiction whose law is chosen. ${ }^{45}$ For instance, a Mexican customer

by which the licence granted to Abaco Grupo Financiero S.A. de C.V. to operate as a financial group is revoked], SECRETARÍA DE GOBERNACIÓN (Mar. 24, 2011), http://dof .gob.mx/nota_detalle.php?codigo $=5183068 \&$ fecha $=24 / 03 / 2011$. See also Juzgado Octavo de Distrito en Materia Civil el Distrito Federal [JDMC] [Eight District Court on Civil Matters of the Federal District], 130/2006 (Mex.).

41 The Convention on the Law Applicable to Certain Rights in Respect of Securities Held with an Intermediary, July 5, 2006, 46 I.L.M. 649 [hereinafter Hague Securities Convention].

42 Richard Potok, The Hague Securities Convention, Closer and Closer to a Reality, 15 J. BANKING \& FIN. L. \& PRAC. 204, 210 (2004).

43 Philipp Paech, Capital Markets Union, Investment Securities and the Tradition of Casting Liquidity into the Law 14 (London School of Econ. and Pol. Sci., Law, Soc'y and Econ., Working Paper No. 20, 2015).

44 See further Stephen J. Kozey, The Hague Securities Convention: An Opportunity to Take UCC Global, 46 GEO. J. INT’L. L. 1213, 1226 (2015).

45 Permanent Editorial Bd. of the Uniform Commercial Code, Hague SECURITIES CONVENTION'S EFFECT ON DETERMining THE APPLICABLE LAW FOR Indirectly Held SeCurities, Draft fOr Public Comment (April 29, 2013), 
and U.S. intermediary may choose Mexican law to govern their relationship provided the intermediary has an office in Mexico.

The Hague Securities Convention entered into effect on April 1, 2017, after the United States deposited the required third ratification instrument at The Hague. ${ }^{46}$ The two other ratifying countries are Mauritius and Switzerland. ${ }^{47}$ Even though only three countries have ratified the Hague Securities Convention as of August 1, 2017, its impact is not trivial considering that the Convention applies "whether or not the law to which the Convention points is that of a country that has adopted the Convention." 48

PRIMA is not the connecting factor to establish the applicable law for directly-held securities for which the location of a security certificate, debtor, or issuer may determine the applicable law. It has been observed that PRIMA is most suitable for holding systems where a distinct property right, such as a security entitlement, is created at intermediary level, as under UCC Article $8 .{ }^{49}$ Mexico does not have such a holding system in which distinct property rights would exist at different levels in the holding chain. ${ }^{50}$ To determine the applicable law for property aspects of securities held with intermediaries, Mexico continues to apply the location of the securities (lex res sitae) as the connecting factor. Incorporation of the PRIMA concept would provide certainty and predictability for securities held through Indeval and Mexican brokerage houses.

http://www.accfl.com/assets/docs/accfl_1-24-17_briefing_peb_hague-convention-draft .pdf.

46 See Status Table: Convention of 5 July 2006 on the Law Applicable to Certain Rights in Respect of Securities held with an Intermediary, HAGUE CONFERENCE ON PRIVATE INT'L LAw, https://www.hcch.net/en/instruments/conventions/status-table/?cid=72 (last updated Dec. 15, 2016).

$47 \mathrm{Id}$.

48 Sandra M. Rocks et al., Memorandum, The Hague Securities Convention Goes Live April 1, 2017, Cleary GotTlieB (Mar. 29, 2017), https://www.clearygottlieb.com / /media/cgsh/files/publication-pdfs/alert-memos/hague-securities-convention.pdf.

49 Compare Francisco Garcimartín \& Florence Guillaume, Conflict of Laws Rules, in TransNational SeCurities LAW 308 (Thomas Keijser ed., 2014) (arguing that the PRIMA approach "does not fit well with substantive laws based on a direct proprietary right of the final investor . . .over the securities deposited or registered at the issuer central securities depository (CSD)"), with Christophe Bernasconi \& Harry C. Sigman, Myths about the Hague Convention Debunked, 24 INT'L FIN. L. REV. 31, 33 (2005) (arguing that “. . . a substantial effort was made to formulate a text that would work with all legal systems and all the variations to be found within each system").

50 See Garcimartín, supra note 30, at 39 (Some experts have suggested that countries such as Mexico should adopt PRIMA.). 
In order to "enhance the internal soundness of national financial markets and their cross-border compatibility," UNIDROIT adopted the Convention on Substantive Rules for Intermediated Securities, also known as the Geneva Securities Convention. ${ }^{51}$ The Official Commentary to the Geneva Securities Convention notes that many intermediated systems are governed by the traditional legal concepts developed for tangible assets deposited with third parties, thus leading to legal risks and uncertainty when these concepts are applied to paperless securities held in accounts with intermediaries, including for buyers and secured creditors. ${ }^{52}$ The Mexican intermediated holding system is an example. The Geneva Securities Convention defers to nonConvention law to provide solutions to a number of open questions, some of which UNIDROIT recently elaborated on in the Legislative Guide on Intermediated Securities (Legislative Guide), ${ }^{53}$ adopted by UNIDROIT's Governing Council in May 2017. Such additional guidance is especially welcome because the Geneva Securities Convention adopted core and functional approaches, addressing only the main aspects of intermediated securities holding and transfers necessary for ensuring internal soundness and compatibility of systems and allowing states to exercise their powers within their legal and regulatory space. ${ }^{54}$ For example, notions such as proprietary interests were not addressed in the Geneva Securities Convention, and Article 9(1) of the Geneva Securities Convention sets out only the features of the legal right acquired under the applicable law. ${ }^{55}$ In addition to providing the necessary guidance on how to adjust domestic law, the Legislative Guide also identifies the factors to be taken into account when submitting a declaration as part of the ratification process. These

51 KANDA ET AL., supra note 1, $\uparrow$ Int-1.

52 Id. $\mid$ Int-2.

53 INT'L INST. FOR THE UNIFICATION OF PRIVATE LAW [UNIDROIT], UNIDROIT Legislative Guide on InTERmediated SeCurities: IMPLEMENTING THE PRINCIPLES AND Rules of the Geneva SeCurities Convention, II 2 (2017), http://www.uni droit.org/english/governments/councildocuments/2017session/cd-96-05-e.pdf [hereinafter LEGISLATIVE GUIDE] ("The Guide. . . seeks to improve the legal framework for holding and transfer of intermediated securities, in order to enhance the internal soundness of domestic financial markets and their cross-border compatibility and, as such, to promote sustainable capital formation.").

54 KANDA ET AL., supra note 1, ๆ Int-20.

55 Id. $\uparrow \uparrow$ Int-20, 9-3. 
two instruments should guide countries like Mexico in their modernization efforts. ${ }^{56}$

Intermediated systems may be generally categorized as indirect (e.g., those governed by UCC Article 8) and transparent (e.g., France). The latter come in a number of varieties. ${ }^{57}$ In the preparatory work leading to the adoption of the Geneva Securities Convention, three categories of transparent systems were identified: (1) those where the CSD maintains customer-specific securities accounts, (2) those where the CSD maintains securities accounts for intermediaries that are subdivided into customer-specific sub-accounts, and (3) those where the CSD regularly consolidates the securities accounts it maintains with the securities accounts that its participants maintain for their customers. ${ }^{58}$ A common feature of the transparent systems is that the CSD knows the identity of the ultimate account holders.

In terms of the property rights of investors, the Legislative Guide divides intermediated holding systems into the following categories: (1) individual ownership models under which the account holder is the full owner of the securities (e.g., in France); (2) co-ownership models under which the account holder of a security has a shared (fractional) interest in the global certificate deposited with the CSD (e.g., Germany); (3) trust models under which the account holder acquires an equitable interest in the securities (e.g., England); (4) security entitlement models under which the account holder has a package of property and contractual rights exercisable only against its intermediary (e.g., the United States); and (5) contractual models under which the account holder acquires a bundle of contractual rights against the relevant intermediary. ${ }^{59}$ From the perspective of the nature of the rights held by account holders, the Mexican intermediate system, as explained below, is a co-ownership system ${ }^{60}$ in which investors, not brokerage houses or Indeval (i.e., intermediaries), are considered co-

56 See Eva Micheler, Transfer of Intermediated Securities and Legal Certainty, in Transnational Securities Law 131 (Thomas Keijser ed., 2014) (observing that the Geneva Securities Convention could be a useful tool for legislators).

57 DuBOVEC, supra note 5, at 65-66; LEGISLATIVE GUIDE, supra note 53, ๆ 55.

58 LEGISLATIVE GUIDE, supra note 53, ๆฯ 39-50.

59 Id. ๆๆ 39-48. See also id. १ฯ 49-50 (Furthermore, some states have a contractual model under which the investors do not acquire any property rights in the securities.).

60 Luc Thévenoz, Intermediated Securities, Legal Risk, and the International Harmonization of Commercial Law, 13 STAN. J. L. BUS. \& FIN. 384, 405-06 (2008). 
owners of intermediated securities ${ }^{61}$ Furthermore, as is common to coownership systems in which CSDs do not know the identity of ultimate account holders, Indeval does not know the identity of account holders who are customers of brokerage houses. ${ }^{62}$

\section{III}

\section{The Process of IMMobilization OF SECURITIES IN MEXICO AND THE TYPES OF SECURITIES ACCOUNTS}

This Part examines only the processes which are relevant to the scope of this Article, leaving aside those related to the requirements of general securities laws, such as adequate disclosures. As this Article focuses only on private securities, government-issued bonds and similar securities are excluded from the discussion. ${ }^{63}$ For a private company to introduce securities into the Mexican intermediate system, the issuer must follow a number of steps. One of the first steps that an issuer must take is to enter into an "adhesion contract for the issuance of securities" with Indeval (contrato de adhesión suscrito por emisores). ${ }^{64}$ The adhesion contract governs aspects of the issuerIndeval relationships such as the payment and distribution of dividends, maintenance of the traditional corporate registry required by law for registered securities, and the availability and process of withdrawal of securities.

61 Pedro Alfonso Labariega Villanueva, El Instituto Para el Depósito de Valores, 99 in ANUARIO JURÍDICO XI 1984, INSTITUTO DE INVESTIGACIONES JURÍDICAS UNIVERSIDAD NACIONAL AUTÓNOMA DE MÉXICO, https://archivos.juridicas.unam.mx/www/bjv/libros 15/2108/6.pdf (last visited Aug. 20, 2017). See also Hector Reynaldo Tinoco Jaramillo, Modalidades que Introduce el Depósito Centralizado de Valores a la Teoría General de los Títulos de Crédito [Modalities that Introduce the Centralized Deposit of Securities to the General Legal Doctrine of Securities] 84 (1981) (Unpublished Professional Thesis, Escuela Libre de Derecho).

62 Id. See also Hideki Kanda, Book-Entry Operations and Property Law, 16 UNIF. L. REV. 13, 15 (2011); LEGISLATIVE GuIDE, supra note 53, ๆ 43. The Mexican intermediated system closely resembles the system of Figure 3: Jurisdiction Type 2 in this Article.

63 Most physical government securities are immobilized or deposited at the Mexican Central Bank, but transacted by way of debits and credits through Indeval. In other words, the Mexican Central Bank is an account holder of Indeval (i.e., depositor). See Lorenzo Jiménez-Vázquez, Securities settlement, in Banco de Mexico, The Mexican Government Securities (2014), http://www.banxico.org.mx/elib/mercado-valores-gub-en/OEBPS/Text /vien.html\#_ftn1 (last visited Feb. 17, 2018).

64 RULES ON DEPOSIT, supra note 16, art. 1.04.00 (defining the terms "adhesion contract" and "issuer"). 


\section{A. Immobilization Steps and Rights Arising Therefrom}

Despite the existence of a contractual relationship with Indeval, the issuer cannot deposit its securities directly at Indeval; it can only do so through an authorized brokerage house. ${ }^{65}$ In a typical initial public offering, an issuer delivers either multiple certificates or a global certificate (certificado global) to an authorized brokerage house that acts as its depositor vis-à-vis Indeval. ${ }^{66}$ Since 2014 , securities may be electronically deposited at Indeval under the rules of the Commercial Code and the regulations issued by the Mexican Central Bank. ${ }^{67}$ Reflecting this process, Mexican legal doctrine characterizes the relationship between the brokerage house and Indeval as a deposit. ${ }^{68}$ This characterization is common for the relationship between an intermediary and customers, where the former functionally acts as a common law bailee. ${ }^{69}$ According to Indeval's Internal Regulations, a depositor is defined as "a person that deposits securities at and signs an adhesion contract of deposit (contrato de adhesión para depositantes) with Indeval." ${ }^{70}$ Only the following entities are authorized to act as depositors: (1) the Mexican Central Bank; (2) national and foreign financial entities as defined in the $2005 \mathrm{LMV}$, including brokerage houses, insurance companies, banks, and factoring companies; (3) foreign central securities depositories; and (4) persons designated by the National Banking and Securities Commission. ${ }^{71}$ Accordingly, only

65 Telephone Interview with Yamil Patiño Muñoz, Legal Department, INDEVAL (Sept. 12, 2016).

66 Jesús Bugeda lanzas, El Depósito Centralizado de Valores [The Centralized Deposit of Securities], ACADEmia de Derecho Bursátil A.C. 323 (Sept. 1980) (Mex.). See also RULES ON DEPOSIT, supra note 16, art. 1.04 .00 (defining the term "depositor").

672005 LMV, supra note 10, art. 282.

68 LANZAS, supra note 66, at 328-32.

69 Charles W. Mooney Jr. \& Guy Morton, Harmonizing Insolvency Law for Intermediated Securities: The Way Forward, in TRANSNATIONAL SECURITIES LAW 199 (Thomas Keijser ed., 2014). It should be noted that there is an important difference between the civil law concept of deposit and the common law concept of bailment. For more on this, see Michael H. Rubin, Bailment and Deposit in Louisiana, 35 LA. L. REV. 825 (1975).

70 See INDEVAL INTERNAL REGULATIONS, supra note 15, art. 2.

$71 \mathrm{Id}$. 
regulated entities may act as intermediaries in the securities holding chain. ${ }^{72}$ Issuers have no securities or cash accounts with Indeval. ${ }^{73}$

A security may be deposited with Indeval for three different purposes recognized by Indeval's Internal Regulations, namely: (1) deposit for custody (depósito en custodia); (2) deposit for administration (depósito en administración); and (3) deposit under a security interest (depósito en garantía). ${ }^{74}$ Indeval assumes different duties under each type of deposit. Under a deposit for custody, Indeval only has a duty to safeguard the deposited securities, acting like a mere custodian. ${ }^{75}$ Under a deposit for administration purposes, Indeval has a duty to perform acts necessary for preserving the property rights (derechos patrimoniales) conferred by the securities on their actual holders. ${ }^{76}$ As such, Indeval is, inter alia, authorized to collect and disburse dividends and interest payments distributed on account of the deposited securities. ${ }^{77}$ Finally, under a deposit for security interest, Indeval has a duty to keep the deposited securities as collateral in a specially designated account until the secured obligation is extinguished or the secured creditor instructs it otherwise. ${ }^{78}$ Indeval is also required to exercise the rights derived from the deposited securities and to act on the instructions provided by brokerage houses. ${ }^{79}$ For instance, for voting purposes, Indeval may issue certificates representing the deposited securities to the brokerage house. The brokerage house sends that information to the issuer together with a list of holders. The certificates and the list are used by the issuer to determine who has the right to vote.

After the adhesion contract of deposit has been executed, Indeval must discharge its duty to accept a security for deposit by opening a securities account. First, as part of its duty to accept a security in custody, Indeval may open an issuance account for the holding of

72 Article 5 of the Geneva Securities Convention allows states to limit its application only to regulated intermediaries. See further KANDA ET AL, supra note 1, 9-1 to 5-13.

73 Telephone Interview with Yamil Patiño Muñoz, Legal Department, INDEVAL (Sept. 12, 2016).

74 BANCO DE MÉXICO, supra note 14, at 166-67.

$75 \mathrm{Id}$.

$76 \mathrm{Id}$.

77 Id. See also Michel Deschamps, Convention on Substantive Rules for Intermediated Securities, Oct. 9, 2009 INT'L INST. FOR THE UNIFICATION OF PRIVATE LAW [UNIDROIT] art. 10(2)(f), http://www.unidroit.org/instruments/capital-markets/geneva-convention (last updated Sept. 25, 2013).

78 BANCO DE MÉXICO, supra note 14, at 166-67.

79 INDEVAL INTERNAL REGULATIONS, supra note 15, art. 19. 
unsubscribed and unpaid securities. Securities are held in the issuance account until they have been subscribed to and paid for by an investor who could be the broker itself or its customers. ${ }^{80}$ The second type of securities account is the ownership account to which securities of brokerage houses and their customers are credited (deposit for administration purposes). Finally, Indeval maintains pledge accounts in which it holds encumbered securities (deposit under security interest) ${ }^{81}$ Ownership accounts are subdivided into two categories: (1) a proprietary account (cuenta propia), and (2) a third-party account (cuenta de terceros). ${ }^{82}$ This means that securities of the brokerage house, and those of its clients, are segregated and maintained separately. ${ }^{83}$ Note that holding sufficient securities for its customers is a core duty imposed on intermediaries under Article 24 of the Geneva Securities Convention in order to ensure the integrity of the system. ${ }^{84}$ This segregation of customer securities in separate accounts maintained by Indeval also satisfies Article 25 of the Geneva Securities Convention, which governs allocation of securities to account holders' rights.

It should be noted that there is no specific rule in Mexican law comparable to Article 26 of the Geneva Securities Convention, which allocates losses among customers pro-rata on an issue-by-issue basis in case there is a shortfall in securities held in the third-party account. ${ }^{85}$ The 2005 LMV does not include a similar formula, but Article 156(IV)(d) provides that all assets owned by the brokerage house must be used to cover claims of third-party holders whenever there is a shortfall of securities (or cash) in the third-party accounts administered by the brokerage house. ${ }^{86}$ The caveat is that no distributions may be made when the assets owned by the brokerage house have been encumbered. ${ }^{87}$ In other words, on insolvency of the intermediary,

\footnotetext{
80 Michel Deschamps, The Best Rules for Non-Intermediated Securities, in TRANSNATIONAL SECURITIES LAW 5 (Thomas Keijser ed., 2014) (This procedure reflects the common corporate law requirement that securities are issued only after they have been fully paid.).

81 RULES ON DEPOSIT, supra note 16, art. 3.06.00.

$82 \mathrm{Id}$.

83 Id. art. 3.01.00.

84 KANDA ET AL., supra note 1, ๆ 24-1. See also LEGISLATIVE GUIDE, supra note 53, 209.

85 See also LeGISLATIVE GUIDE, supra note 53, \ 260.

862005 LMV, supra note 10, art. 156(IV)(d).

$87 \mathrm{Id}$.
} 
where there is a shortfall in securities or cash of its customers, their outstanding claims will be satisfied from the assets of the intermediary, typically securities and cash. However, the customers will not be entitled to any satisfaction from the intermediary's assets if they are encumbered-i.e., if the intermediary used securities and cash as collateral to secure its own obligations. If there is a shortfall in the customer securities and the brokerage does not own any securities that could cover the shortfall, the absence of a specific loss allocation formula leaves a gap that may need to be filled in by the courts applying the general principles of Mexican property law. Unlike the Legislative Guide, which recommends the adoption of a scheme to protect retail customers of intermediaries, ${ }^{88}$ Mexico does not have a customer protection or insurance scheme that would protect securities holders against shortfalls resulting from the insolvency of their intermediaries. One could expect that the Mexican courts would apply the Civil Code rule of proportional ownership that allocates losses proportionately among investors according to the size of their original claims. ${ }^{89}$ This is another illustration of the risks resulting from a legal system constructed on the traditional principles of direct holding that rely on the general rules of the Civil Code to fill in gaps. The absence of a clear statutory rule adds to the unpredictability of the securities holding system, and increases risk premiums for its participants. Such a rule should be coupled with the power of a supervisory agency or insolvency court administering the insolvency of the intermediary to swiftly return securities and cash to the customers or transfer their securities accounts to a solvent intermediary.

\section{B. Moving Down the Holding Tiers}

Upon issuance, Indeval credits the securities to the issuance account of the authorized brokerage house. ${ }^{90}$ Subsequently, the brokerage house engages its customers and other investors to sell the securities. ${ }^{91}$ Securities must be paid in order to be credited to the third-party account maintained under the ownership account held by Indeval for the

\footnotetext{
88 Legislative Guide, supra note 53, ๆ 269.

89 See James Steven Rogers, Negotiability, Property, and Identity, 12 CARDOZO L. REV. 471, 485 (1990) (noting that "UCC Article 7 adopts more or less the same approach as the Article 8 'proportionate ownership' rule for securities held in fungible bulk"); see also Civil Code, supra note 12, arts. 940-42.

90 RULES ON DEPOSIT, supra note 16, art. 3.01.00.

91 LANZAS, supra note 66, at 324-26.
} 
brokerage house. ${ }^{92}$ Accordingly, when an investor buys one hundred shares of an issue, Indeval will debit the proprietary account of the brokerage house and credit the securities to the third-party account. The third-party ownership account maintained by the brokerage may be of two varieties: (1) an omnibus account (cuenta de terceros ómnibus), where Indeval does not know the identity of the brokerage house's customers; and (2) a non-omnibus account (cuenta de terceros), held for other financial institutions (e.g., banks) for securities owned by the financial institutions' customers. ${ }^{93}$ The other financial institutions act like a second-tier intermediary. Indeval only knows the identity of the other financial institutions, but not the identities of their customers who may be the actual investors. ${ }^{94}$ It is common practice for banks to hold a third-party non-omnibus ownership account with Indeval through an authorized brokerage house. ${ }^{95}$ It should be noted that banks can also establish a direct relationship with Indeval by entering into an adhesion contract of deposit. ${ }^{96}$ Whether the bank has a direct relationship with Indeval, or interacts with Indeval only indirectly through an authorized brokerage house, Indeval does not know the identity of the bank's customers (for whom it maintains securities accounts). ${ }^{97}$ In summary, Indeval maintains both proprietary and third-party securities accounts for brokerage houses. The third-party account (for the holding of customers' securities) may be maintained as an omnibus or nonomnibus account. Overall, Indeval neither knows the identity of the brokerage house customers whose securities are held in an omnibus third-party account or those of banks that have non-omnibus accounts.

The relationship between brokerage houses and their customers is based on the mercantile agency concept (comisión mercantil). ${ }^{98}$ Under

92 Id.

93 RULES ON DEPOSIT, supra note 16, art. 3.16.00.

94 Telephone Interview with Yamil Patiño Muñoz, supra note 65.

95 Id.

96 OPERATIONS MANUAL OF SERVICES FOR THE FUlFillment OF DePOSITORS' OBLIGATIONS, supra note 17, art. 2. See also Ley de Instituciones de Crédito [LIC] [Credit Institutions Law], as amended, art. 46 (XVI), Diario Oficial de la Federación [DOF], 17 de Junio de 2016 (Mex.), http://www.diputados.gob.mx/LeyesBiblio/pdf/43_170616.pdf [hereinafter Credit Institutions Law].

97 Telephone Interview with Jesús Mondragón, Director of Custody and Control, INDEVAL (Jan. 15, 2014). See also Tinoco, supra note 61; Raul Fernando CárdenasEcheyenne, La Caución Bursátil 50 (1994) (unpublished professional thesis, Escuela Libre de Derecho) (on file with authors).

98 LANZAS, supra note 66, at 329. See also 2005 LMV, supra note 10, art. 2; Commercial Code, supra note 11 , arts. 273-308. 
the mercantile agency concept, the agent (comisionista) may be personally responsible to third parties for transactions entered into on behalf of the principal (comitente). The agent's responsibility depends on whether the agency relationship was disclosed to the third party. If the agent discloses the principal's identity or the existence of an agency relationship to a third party, the agent is not personally responsible and their rights and duties as against the third party are governed by general law (derecho común) (e.g., Civil Code). ${ }^{99}$ According to Article 199 of the 2005 LMV, a customer must enter into a financial intermediation agreement (contrato de intermediación bursátil) with a brokerage house. ${ }^{100}$ The brokerage house can open a securities account for the customer only after the financial intermediation agreement has been executed. According to regulations issued by the National Banking and Securities Commission, each brokerage house must set up and maintain an electronic system known as "system for receipt, registration and execution of (investors') orders" to communicate investors' orders to the securities exchange. ${ }^{101}$ Before carrying out an order, brokerage houses must first verify that the investor's account has sufficient securities to complete a transfer. ${ }^{102}$ In addition, whenever the brokerage house receives a sell order, it must verify whether the securities are encumbered by a pledge and, if so, reject the order. ${ }^{103}$

Brokerage houses must issue a confirmation (comprobante de operación) for each transaction entered into pursuant to customers'

\footnotetext{
99 Commercial Code, supra note 11, art. 285.

100 The Intermediation Agreement governs aspects such as the terms of the agency relationship between a brokerage house and individual investors, the duties of the brokerage house with regards to the deposit and administration (e.g., exercise of voting rights of investors/shareholders) of securities, a description of the type of transactions brokerage houses are authorize to enter into on behalf of investors (e.g., pledge of securities), and general provisions (e.g., securities account information, payment system used, investors' instructions, securities' statements, etc.). Contrato de Intermediación Bursátil [Stock Brokerage Contract], BANORTE IXE CASA DE BOLSA, https://www.banorte.com/wps /wcm/connect/ixe-xima/2262b03a-dd4e-444d-b2fe-33471123abf7/nuevo-contratointermediacion-bursatil.pdf?MOD $=$ AJPERES $\&$ ContentCache $=$ NONE (last visited Aug. 18, 2017) [hereinafter Intermediation Agreement].

101 CIRCULAR 10-237, Sistema Automatizado para la Recepción, Registro, Ejecución y Asignación de Operaciones Con Valores. Disposiciones Aplicables [CIRCULAR 10-237, Automated System for the Reception, Registration, Execution and Assignment of Operations with Values. Applicable Provisions], SeCRetaría de HaCienda y CRÉdito PúBlico, (Feb. 1, 2000), http://www.shcp.gob.mx/LASHCP/MarcoJuridico/documentos DOF/arch ivos_shcp_dof/circulares/c10_237.html.

102 Id.

103 Id.
} 
instructions. ${ }^{104}$ Every confirmation must be reflected in the monthly securities account statement that is provided to the customer no later than five days following the close of the monthly cycle. ${ }^{105}$ According to the intermediation agreement, the securities statement "acts as the acknowledgement of deposit and voucher or deposit slip (resguardo) of the securities credited to the customer's securities account."106 Again, the reference to deposit is a relic that attempts to adapt the traditional concept of holding goods on behalf of others to electronic securities evidenced by entries in accounts.

For purposes of acquiring rights to the securities, only securities credited to the brokerage house's third-party omnibus account at Indeval will be considered as actually received by the brokerage house and thus acquired by and held for the customer. ${ }^{107}$ In other words, a credit of securities to a customer's account by the brokerage house does not constitute any rights to those securities, unless Indeval also credited the securities to the brokerage house's third-party account. Where the seller's securities are credited to the same brokerage houses' third-party omnibus account, the buyer acquires rights thereto when the brokerage confirms the sale to the buyer in a statement. Accordingly, the securities statement may not only reflect the investors' securities holdings, but also establish title to the securities. ${ }^{108}$

\section{IV \\ THE FOUNDATIONS OF THE MEXICAN INTERMEDIATED SECURITIES SYSTEM}

Among the most relevant legal institutions underpinning the current intermediated holding system are: (1) the definition of securities, (2) negotiability, (3) the legal institution of deposit, (4) the endorsement (for administration purposes), (5) the commercial agency contract, and (6) the possessory pledge. Understanding these legal institutions (including the relationships between Indeval, the brokerage houses, customers, and secured creditors) is crucial for understanding the Mexican intermediated system as a whole. As mentioned above, the

104 Intermediation Agreement, supra note 100, at 24. See also 2005 LMV, supra note 10, art. 200 (IV).

105 Intermediation Agreement, supra note 100, at 24 (The statement identifies securities by issuer, type, and series.).

106 Id.

107 Id.

108 Garcimartín, supra note 30, at 33. 
general legal doctrine of securities, as developed in Mexico, is also an element underpinning the intermediated system. This doctrine was "bent" to fit this new holding pattern.

One of commercial law's greatest innovations was to treat intangible rights, such as rights to future cash flows derived from bonds and shares, as if they were tangible property. ${ }^{109}$ As such, intangible rights can be transferred in accordance with the rules governing negotiable instruments. This allows investors to prove and assert their rights by way of possession and transfer them by delivering certificates to buyers or secured creditors. ${ }^{110}$ Negotiability serves functions performed by other systems for the recognition of proprietary interests, including filing systems in respect of security interests and real property recording systems. ${ }^{111}$ Negotiation originated from medieval commercial practices with promises such as Mediterranean promissory notes and bills of exchange. Impersonal markets for securities originated in the fourteenth century for the trading of the public debt of Italian city-states. ${ }^{112}$ Certificated securities are not only evidence of the rights issued, but also movable vehicles whose transfer-according to the laws governing personal property - "also operated the transfer of the intangible rights 'attached to' or 'incorporated in' them." the essence of the reification doctrine which facilitates transfers of intangible rights through the delivery of representative certificates. ${ }^{114}$

The general legal doctrine of securities explains, inter alia, how rights evidenced by certificates could be sold, pledged, or otherwise transferred. This doctrine is embodied in Article 5 of Mexico's General Law of Securities and Credit Operations, ${ }^{115}$ which provides that "documents necessary to exercise the actual right reified in them are

109 LuC ThÉvenoz, The Geneva SECurities Convention: OBJeCtives, History AND Guiding PRinciPles 3-5 (Pierre-Henri Conac, Ulrich Segna \& Luc Thévenoz eds., 2013).

110 Thévenoz, supra note 60 , at 385-86.

111 James Steven Rogers, Negotiability as a System of Title Recognition, 48 OHIO ST. L.J. 197, 201 (1987).

112 Rogers, supra note 89 , at 471.

113 THÉVENOZ, supra note 109, at 4.

114 Reification also underpinned UCC Article 8's rules with respect to the transfer of security certificates. James Steven Rogers, Policy Perspectives on Revised U.C.C. Article 8, 43 UCLA L. REV. 1431, 1455 (1996).

115 LGTOC, supra note 7, art. 5. 
considered as credit instruments (titulos de crédito)." ${ }^{" 16}$ Mexican legal doctrine has identified at least five characteristics or principles common to securities: (1) incorporation, (2) legitimation or legal standing, (3) literalness, (4) autonomy, and circulation/negotiability. ${ }^{117}$ Incorporation means that the actual right has been embodied in a document-an act that creates a security. ${ }^{118}$ This act merges an intangible right into its tangible representation, becoming one item. ${ }^{119}$ Incorporation is thus a synonym for reification. Legitimation is understood as a consequence of incorporation because the rights evidenced by the certificate can only be exercised by its holder; as such, only the person holding the certificate has legal standing to exercise rights against the issuer. ${ }^{120}$ Literalness is interpreted as the measure of both the quantity and quality of rights and obligations embedded in the certificate. ${ }^{121}$ Accordingly, the certificate reflects the amount invested as well as the terms and conditions under which the holder may enforce its rights - the literal interpretation of which prevails over the extrinsic circumstances. The autonomy element has been interpreted to bestow a status on the rights and obligations of a holder independent from the rights and obligations of any previous holders. ${ }^{122}$ Finally, the circulation characteristic has been interpreted as the intrinsic ability of securities to be efficiently negotiated or otherwise transferred. ${ }^{123}$

Evidently, these principles were designed to govern certificated securities. However, these principles, in large measure, underpin the legal framework governing the current intermediated securities system. Applying some of these traditional principles, such as negotiability, to transfers by book entries is difficult. ${ }^{124}$ For some principles (e.g., autonomy), specific provisions have been inserted in the legislation. For instance, according to Article 283 of the 2005 LMV, whenever the transfer of securities is effectuated by book-entries, "the personal

116 The "credit instrument" concept of the General Law for Securities and Credit Operations includes not only securities, but also documents of title and negotiable instruments.

117 AHUMADA, supra note 6, at 10-15.

118 LGTC, supra note 7, arts. 5, 17 \& 18.

119 DURAN, supra note 26, at 25.

$120 \mathrm{Id}$. at 27.

$121 \mathrm{Id}$. at 28.

$122 \mathrm{Id}$. at 32.

123 Id. at 39-40.

1242005 LMV, supra note 10, art. 283. 
exceptions of the person who sold the securities to the transferor cannot be asserted against the transferee." 125 The negotiability-based title recognition system (abandoned in UCC Article 8) should be preserved only for certificated securities under the Mexican law because the system for the holding of intermediated securities no longer relies on possession of certificates, but rather entries in accounts maintained by Indeval. ${ }^{126}$ As under UCC Article 8, "the possession based system of title recognition of negotiable instruments law has effectively been supplanted by a system based on notations on records of intermediaries," i.e., Indeval. ${ }^{127}$ Such a system requires a rule similar to UCC Section 8-502, which protects transferees of intermediated securities by credits to their securities accounts.

Securities in Mexico are categorized as personal property under Articles 754 and 755 of the Civil Code. ${ }^{128}$ Article 755 of the Civil Code defines shares as "movable assets since they were conceived for the

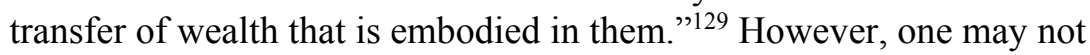
find a rule in Mexican law that draws a clear dividing line between tangible and intangible assets. ${ }^{130}$ As will be seen below, the categorization of securities as tangible assets was fundamental in the design of the Mexican system as one based on deposit. The deposit, governed by the Civil Code ${ }^{131}$ and the Commercial Code, ${ }^{132}$ is central to the operation of the Mexican intermediated system. According to Article 2516 of the Civil Code, the "deposit is a contract by which the depositary or custodian receives an asset from the depositor that must be returned upon the depositor's request." 133 Article 332 of the Commercial Code provides that "a deposit is deemed commercial whenever the assets are tradeable, or if the deposit is entered into

125 Id. ("No se podrán oponer al adquirente de valores nominativos por el procedimiento establecido en este artículo, las excepciones personales del obligado anteriores a la transmisión contra el autor de la misma.").

126 For the conceptual underpinning of the UCC Article 8 system, see Rogers, supra note 111 , at 207.

127 Id. at 208.

128 Civil Code, supra note 12, arts. 754-55. See also AHUMADA, supra note 6, at 43.

129 DURAN, supra note 26, at 32.

130 Rojina Villegas Rafael, Derecho CiVIL MeXiCANo: BIENEs Derechos ReAles Y POSESIÓn 284 (Manuel Porrúa ed., 1995). See also STEPHEN ZAMORA ET AL., MEXICAN LAW 486-87 (2004).

131 Civil Code, supra note 12, arts. 2516-38.

132 Commercial Code, supra note 11, arts. 332-39.

133 Civil Code, supra note 12, art. 2516. 
pursuant to a commercial transaction."134 Mexican doctrine classifies deposit into two types: regular and irregular. ${ }^{135}$ The main difference is that under an irregular deposit, the depositary acquires ownership rights over the deposited assets and must return goods of the same kind and quality to the depositor. But under a regular deposit, the depositary only acquires custodial or possessory rights and must return the exact object. ${ }^{136}$ Ultimately, the intention of the parties to the contract of deposit determines the nature of the deposit. ${ }^{137}$ Because ownership rights have been transferred to the depositary under an irregular deposit, a depositary's creditors could have access to the deposited assets in case of a default. ${ }^{138}$ The deposit of securities at Indeval is a regular deposit, as a result of which creditors of Indeval, however hypothetical that scenario might be, cannot assert any rights against the securities held by Indeval. ${ }^{139}$ Indeval does not act as the owner of the deposited securities, but merely as a custodian/administrator. According to Article 2518 of the Civil Code, whenever securities are deposited with a depositary, the latter must exercise the property rights embedded in the deposited securities on behalf of the depositor. ${ }^{140}$ The actual duty to exercise those rights on behalf of the depositor and the manner in which they are exercised, including to effect transfers by credits and debits, is governed by the 2005 LMV and the adhesion contract of deposit between Indeval and the brokerage house. ${ }^{141}$ Pursuant to Article 283 of the 2005 LMV, “. . . the transfer of securities will be completed by entries in the registry maintained by the depository institution [Indeval], and [the securities'] physical delivery, endorsement or, when applicable, their registration in the issuers' records." 142 As earlier mentioned, even though they have a contractual relationship with Indeval, issuers cannot directly deposit their securities at Indeval. Accordingly, the deposit relationship is governed by the terms of the adhesion contract of deposit between Indeval and

134 Commercial Code, supra note 11, art. 332. See also Civil Code, supra note 12, art. 2516.

135 OSCAR VÁzQuez del MerCado, Contratos MERCANTILES 180-81 (1992).

136 Id.

137 Id.

138 Id.

139 Id. See also Tinoco, supra note 61, at 52.

140 Civil Code, supra note 12, art. 2518.

141 Id. See also 2005 LMV, supra note 10, art. 283.

1422005 LMV, supra note 10, art. 283. 
depositors who deposit securities to Indeval on behalf of issuers. ${ }^{143}$ The adhesion contract of deposit provides that depositaries may act as "general representatives of holders of securities that are deposited [at Indeval]." "144

One of the innovations of the 2005 LMV was the creation of a new type of endorsement for administration purposes. Only to the order and registered securities (titulos valores nominativos) may be endorsed as such $^{145}$ by the authorized brokerage house prior to their deposit at Indeval. ${ }^{146}$ According to Article 283 of the 2005 LMV, the endorsement for administration purposes confers on Indeval the status of a depositary. ${ }^{147}$ The endorsement for administration purposes empowers Indeval to exercise rights embodied in the deposited securities directly against the issuer. ${ }^{148}$ It should be noted that if the legend "deposited at Indeval" is physically affixed by the issuer to the global certificate at the moment of issuance, the endorsement for administration purposes is no longer required and such a legend has the same legal effects. ${ }^{149}$

The fundamental structure of the intermediation agreement between the brokerage house and a customer is an agency relationship. The agreement is primarily regulated by the 2005 LMV and, subsidiarily, by the Commercial ${ }^{150}$ and Civil Codes. ${ }^{151}$ It is through this contract that customers grant to brokerage houses the power to effect all endorsements, assignments, and transfers of securities. ${ }^{152}$ With respect to third parties, brokerage houses act under their own name without disclosing the customer's identity unless otherwise instructed by their customers or required by law. ${ }^{153}$ Under Mexican law, this type of agency is considered an agency relationship without representation (mandato no representativo). ${ }^{154}$ According to Mexican doctrine, if a

\footnotetext{
143 RULES ON DEPOSIT, supra note 16, Annex I.

144 See Model Adhesion Contract of Deposit, art. I(h) (on file with authors).

1452005 LMV, supra note 10, art. 283.

146 Telephone Interview with Yamil Patiño Muñoz, Legal Department, INDEVAL (Sept. 12, 2016) (on file with authors).

1472005 LMV, supra note 10, art. 283.

148 Tinoco, supra note 61, at 91.

1492005 LMV, supra note 10, art. 282.

150 Commercial Code, supra note 11, arts. 273-308.

151 Civil Code, supra note 12, arts. 2546-61.

1522005 LMV, supra note 10, art. 199.

153 Id.

154 Rafael Rojina Villegas, DeRECho CiVIL MeXiCANO: TOMO SEXTO, CONTRATOS VOLUMEN II 75-78 (Manuel Porrúa ed., 2001).
} 
person sells property to a third party under an agency without representation that authorizes the agent to act without disclosing the identity of the principal, a legal relationship is established between the principal and the third party with respect to the property. ${ }^{155}$

\section{V \\ Pledge Of Securities: FinANCial Pledge of INTERMediated SECURITIES}

The Civil and Commercial Codes, General Law for Securities and Credit Operations, and the General Law for Commercial Corporations govern the pledge of securities held through Indeval. Pledges can be of two varieties: possessory and non-possessory. Pursuant to Article 2858 of the Civil Code, in order for a possessory pledge to be created and perfected, the asset must be delivered either in fact (real) or constructively (juridicamente) to the secured creditor. ${ }^{156}$ With respect to certificated securities, according to Article 334 of the General Law for Securities and Credit Operations, a possessory pledge can be created and perfected by the endorsement of securities and their delivery to the secured creditor or the delivery and registration of the transfer in the records of the issuer. ${ }^{157}$ Mexican law also recognizes a special type of pledge for intermediated securities, known as the financial pledge (prenda bursátil). ${ }^{158}$ The financial pledge was introduced in the 2005 LMV. This pledge replaced a similar legal institution known as "pledge of securities" (garantia prendaria sobre valores), which was introduced as part of the 1978 amendments to the 1975 LMV. ${ }^{159}$ Article 77 of the 1975 LMV (as amended in 1978) provided that a pledge of securities had to be "formalized in writing at [Indeval]" in order for the pledge to be created. The rules governing this security device were later amended in 1980 and 1985, stipulating additional requirements for its creation and introducing extra-judicial

155 Id.

156 Civil Code, supra note 12, art. 2858.

157 LGTOC, supra note 7, art. 334.

158 The financial pledge is subsidiarily governed by "commercial laws [i.e., the General Law for Securities and Credit Operations, the Commerce Code, etc.], financial and commercial usages, and the [Civil Code]." See 2005 LMV, supra note 10, art. 5.

159 Ley del Mercado de Valores [LMV] [Stock Market Law], as amended, art. 77, Diario Oficial de la Federación [DOF], 12-5-1978 (Mex.). 
enforcement rules, respectively. ${ }^{160}$ It was not until 1993 that the caución bursátil contract was introduced into the Mexican legal framework, accompanied by rules on extra-judicial enforcement. ${ }^{161}$

The underlying principles of the financial pledge are characteristic of the classical possessory pledge. This analogy to the possessory pledge led the legislature to prescribe requirements that effectively strip the debtor of any access to the pledged securities, akin to the result under the possessory pledge. The consequence of this misguided approach is that the financial pledge does not recognize the perfection mechanism that would allow the debtor to have access to the pledged securities, as would be the case for a control agreement under UCC Article 9 or the Geneva Securities Convention. ${ }^{162}$ This approach also effectively eliminates any possibility for the debtor to create junior security interests over the same securities no matter how large its equity in those securities might be (e.g., where the secured creditor loaned only thirty percent of the value of the security). ${ }^{163}$

Mexican law provides different rules for financial pledges depending on: (1) whether the issuers of the intermediated securities are financial (e.g., banks) or non-financial entities (e.g., corporations), and (2) the nature of the secured creditor (e.g., the Central Bank). The 2005 LMV governs the financial pledge applicable to intermediated securities issued by corporations. In contrast, the financial pledge covering intermediated securities issued by financial institutions is mainly governed by the Credit Institutions Law (Ley de Instituciones de Crédito $)^{164}$ and is outside the scope of this Article, since it is utilized exclusively for loans granted by the Mexican Central Bank (Banco de México).

Financial pledges can be of two varieties: (1) a financial pledge by which ownership of the securities is transferred to the secured creditor, and (2) a financial pledge under which ownership of the securities

160 Id. See also Ley del Mercado de Valores [LMV] [Stock Market Law], as amended, art. 77, Diario Oficial de la Federación [DOF], 3-4-1985 (Mex.) ("[T]he extra-judicial sale of the pledged securities could be expressly agreed to for situations in which the obligation is due and the debtor fails to satisfy the amount owed ....").

161 Ley del Mercado de Valores [LMV] [Stock Market Law], as amended, art. 99, Diario Oficial de la Federación [DOF], 23-7-1993 (Mex.).

162 See U.C.C. § 9-106 (2010); Deschamps, supra note 77, art. 12(3)(c).

163 On the consequence of pledging an uncertificated security under the 1977 revision of UCC Article 8, see Martin J. Aronstein, Robert Haydock, Jr. \& Donald A. Scott, Article 8 is Ready, 93 HARV. L. REV. 889, 899 (1980).

164 Credit Institutions Law, supra note 96, arts. 29 bis 13-15. 
remains with the pledgor. ${ }^{165}$ In both instances, the securities subject to a security interest are credited to the pledge account of the secured creditor (or pledge administrator). The terms of the financial pledge contract determine which of the two pledges is created. ${ }^{166}$ This approach is consistent with Article 32 of the Geneva Securities Convention, which requires recognition of title transfer collateral agreements.

According to Article 204 of the 2005 LMV, the financial pledge constitutes a right in rem over the securities provided as collateral. ${ }^{167}$ In Mexican practice, contracts typically include clauses that extend the financial pledge to, inter alia: (1) dividends, (2) funds obtained from the sale of pledged securities, (3) securities purchased with proceeds obtained from the sale of the pledged securities, and (4) additional securities (top-up collateral). ${ }^{168}$ The financial pledge is created by a financial pledge contract (contrato de prenda bursátil) between the debtor and secured creditor. ${ }^{169}$ As an additional requirement of creation, Article 204 of the 2005 LMV provides that the debtor, through its brokerage house, must request Indeval to debit its securities account and credit the secured creditor's pledge account (or the pledge administrator's account) with the encumbered securities. ${ }^{170}$ In practice, this request to Indeval is accompanied by a copy of the intermediation agreement between the debtor and the brokerage house, as well as documents regarding each financial pledge contract. ${ }^{171}$ The credit of the securities to the pledge account has been analogized to delivery of possession required by the Civil Code for the creation and perfection of the possessory pledge. ${ }^{172}$ Article 204 of the 2005 LMV provides that a credit entry to the pledge account does not require "endorsement and

165 Id. See also Intermediation Agreement, supra note 100, at 15; Thomas Keijser, Guy Morton \& Marcel Peeters, Financial Collateral: From Private to Regulatory Law Reform, in Transnational Securities Law 29 (Thomas Keijser ed. 2014).

1662005 LMV, supra note 10, art. 204. Under Article 11 of the Geneva Securities Convention, the nature of the right acquired by credit is determined by the parties to the transaction. KANDA ET AL., supra note 1, at 69.

1672005 LMV, supra note 10, art. 204.

168 See Modelo de Contrato de Prenda Bursátil cl. 1 (on file with authors) [hereinafter Financial Pledge Model Contract].

169 Id.

1702005 LMV, supra note 10, art. 204.

171 Intermediation Agreement, supra note 100, at 14.

172 Marcela Castillo Noguerón, Prenda Sobre Valores [Pledge over Securities] 71 (1992) (Unpublished Professional Thesis, Escuela Libre de Derecho) (on file with authors). 
delivery of the securities subject to the pledge to the secured creditor" or "registration of the transfer in the issuer's records." 173 This statement is redundant as endorsement or delivery of the security is not possible when it is held in the form of an entry to a securities account. The pledge is considered created and perfected when a written financial pledge contract is entered into between the debtor and creditor and the securities are actually credited to the pledge account designated by the secured creditor. ${ }^{174}$ Accordingly, the traditional requirements for the creation and perfection of a pledge have been adapted for transactions secured with intermediated securities held in Indeval, without consideration as to whether those requirements are practicable for such collateral and how they affect the liquidity of encumbered securities. Some of these concerns could have been alleviated had the drafters adapted the principles underlying the non-possessory pledge, which might have led to the recognition of control agreements and filing as additional forms of perfection. It remains uncertain what the policy/normative bases of the policymakers were at the time the financial pledge was conceived in its present form. Whatever the policy/normative bases are, they would seem to differ from the policy/normative bases underpinning the current Mexican secured transactions law, which no longer requires such extreme formalities and recognizes notice filing.

Perfection of a pledge of securities by filing or control is thus not available in Mexico. Accordingly, a pledge over all assets of the debtor or assets that include securities as well as some other personal property would require perfection by at least two methods: (1) registration (filing) with Registro Único de Garantías Mobiliarias (RUG), and (2) crediting the encumbered securities to the pledge account. ${ }^{175}$ The effects of crediting pledged securities to a pledge account is not limited to achieving perfection; rather, it essentially prevents the creation of competing, later-in-time, encumbrances. Furthermore, it strips the debtor of access to its securities. This creation and perfection mechanism may be impractical where it is commercially reasonable to provide the debtor with access to securities that may need to be actively managed. The underlying logic of the financial pledge is consistent with the possessory pledge, which is an illustration of the misguided approach to adapt the traditional notions to intermediated securities.

1732005 LMV, supra note 10, art. 204.

174 Id.

175 Commercial Code, supra note 11, art. 32 bis 1-9. 
Still, the regime for the pledging of securities is more restrictive than that for the pledging of general tangible assets where the debtor may have access to the collateral, and even dispose of it, such as under a collateral management arrangement. In such an arrangement, the secured creditor is indirectly in possession of the collateral managed by its agent. The last changes to the Mexican legal framework governing the intermediated system were made in 2014 to recognize the appropriation of the encumbered securities in satisfaction of the secured obligation. At that time, Mexico already had a modern secured transactions system for other personal property, such as inventory and accounts. Any possessory pledge notions that might have motivated the policymakers to introduce such a restrictive concept of the financial pledge were eliminated by the post-2009 wave of reforms to the Commercial Code, which introduced the RUG in 2010.

Perfection of a pledge through a control agreement would provide more flexibility to interested parties and would be consistent with the principles underlying the perfection of a pledge through constructive possession of the collateral. ${ }^{176}$ If the secured creditor is the brokerage house itself, there is no practical need to credit these securities to a pledge account, as the brokerage house would be in a position to exercise control over the collateralized securities by preventing the customer from disposing of them, and could provide notice to third parties that the affected securities are subject to a pledge. Furthermore, this requirement effectively prevents the brokerage house from repledging the securities for which it provided a margin loan, thus increasing the financing cost for the customer. The requirements for the creation and perfection of financial pledges would not correspond to the intent of the Geneva Securities Convention, which is to provide inexpensive and efficient methods of acquiring rights in securities. Finally, the perfection of a pledge over the securities account, rather than just some securities credited to it, would be complicated because the financial pledge, like its traditional pledge-over-tangible-assets

176 Deschamps, supra note 77, arts. 1(k), 12(3)(c); U.C.C. § 8-106(d)(2). The Geneva Securities Convention does not require states to recognize control agreements as a method for the acquisition of rights in securities. See KANDA ET AL, supra note 1, ๆ 1-50. See generally Charles W. Mooney \& Kumiko Koens, Security Interests in Book-Entry Securities in Japan: Should Japanese Law Embrace Perfection by Control Agreement and Security Interests in Securities Accounts?, 37 U. PA. J. INT'L L. 761 (2017). 
counterpart, contemplates delivery of only individual assets rather than the totality of assets. ${ }^{177}$

\section{A. Law Applicable to Pledges of Intermediated Securities}

According to Article 13 (III) of the Civil Code, rights to personal property are governed by the law of the place in which the property is located. ${ }^{178}$ Intermediated securities are intangible rights that have no physical location. If securities were to be immobilized at Indeval, they would be considered located in Mexico. Consequently, Mexican law would apply to the financial pledge with respect to those securities. It should be noted that the Civil Code does not allow the parties to vary the effect of this rule. ${ }^{179}$ Accordingly, the relevant intermediary for all securities held through Indeval, is Indeval. This is a result of the substantive law assimilating securities to tangible assets. ${ }^{180}$ Thus, financial pledges over securities deposited at Indeval and held with Mexican brokerage houses, whether in the form of security or outright transfers, will be governed by Mexican law. ${ }^{181}$ If the customer of a brokerage house acquired intermediated securities immobilized with a non-Mexican CSD, a different law would apply to security interests in those securities, thus increasing the level of complexity and cost of secured transactions as compared to the PRIMA approaches.

\section{B. Pre- and Post-default Rights of the Secured Creditor}

Under the financial pledge, where ownership to the securities remains with the pledgor, the secured creditor assumes the obligations prescribed by Article 388 of the General Law for Securities and Credit Operations. For instance, the secured creditor must exercise all rights inherent to the securities, including applying all amounts derived from the exercise of such rights (e.g., payment of dividends) to the secured obligation. ${ }^{182}$ Since ownership has not been transferred to the secured

177 Deschamps, supra note 77, art. 12(4)(a) (stating that a security interest may be taken over a securities account "and such an interest extends to all intermediated securities from time to time standing to the credit of the relevant securities account").

178 Civil Code, supra note 12, art. 13(III).

179 Id. art. 13(V).

180 See Paech, supra note 43, at 15.

181 Deschamps, supra note 80, at 22 (noting that "the factors that determine the law applicable to an outright transfer and a security interest must be the same").

182 Id. 
creditor, it cannot dispose of the pledged securities. ${ }^{183}$ In contrast, under a financial pledge with transfer of ownership, the secured creditor has the duty of restituting securities of the same class (especie) to the debtor when the secured obligation is satisfied. ${ }^{184}$ Thus, under this type of pledge, the secured creditor has the power to sell the pledged securities as long as securities of the same class are returned to the debtor upon satisfaction of the secured obligation. ${ }^{185}$ Mexican legislators should consider adopting rules to allow secured creditors to dispose of the securities under both types of pledges, subject to some protections for the pledgor. ${ }^{186}$ The current restriction on disposal of securities subject to a financial pledge in which ownership remains with the pledgor negatively affects the rehypothecation market and increases the cost of credit. ${ }^{187}$

The parties to the financial pledge contract are allowed to agree on post-default extra-judicial sale of the securities. ${ }^{188}$ When the core extrajudicial enforcement rules applicable to the financial pledge were introduced in 1985 and 1993, they were viewed as an innovation in Mexican law that was not available with respect to any other type of asset subject to a pledge. Although promoted as a progressive move, the practicalities of enforcing rights extra-judicially were out of step with contemporary market practices. Besides a debtor and secured creditor, there are two other parties involved in an extra-judicial sale of securities subject to a financial pledge: a pledge administrator and a pledge executor. The pledge administrator and the pledge executor can be an authorized brokerage house or financial institution selected by the debtor and secured creditor. These parties are decided in a financial pledge contract written for purposes of administering the pledged securities. ${ }^{189}$ The pledge executor is appointed for the purposes of

183 Id. art. 336. See also 2005 LMV, supra note 10, art. 204; Castillo, supra note 172, at $41-42$.

1842005 LMV, supra note 10, art. 204.

185 Id. See also LGTOC, supra note 7, art. 336; Castillo, supra note 172, at 41-42.

186 Deschamps, supra note 77, art. 34. See also U.C.C. § 9-207(c)(3) (under which the secured party in control may create a security interest in the collateral). Some limits on repledge should be considered. Keijser, Morton \& Peeters, supra note 165, at 45.

187 KANDA ET AL., supra note 1, at 203. Re-hypothecation of stock has its origins in the margin lending practice of U.S. stockbrokers at the beginning of the twentieth century. See Keijser, Morton \& Peeters, supra note 165, at 36.

1882005 LMV, supra note 10, art. 204.

189 Id. 
enforcing the financial pledge. ${ }^{190}$ A pledge administrator, who is appointed primarily for the purpose of quantifying the owed amount, may also act as a pledge executor. ${ }^{191}$ It should be highlighted that through the financial pledge contract the debtor grants an irrevocable commercial power of attorney (mandato irrevocable con carácter de comision mercantil) to both the pledge administrator and pledge executor to use and transfer the pledged securities as necessary. ${ }^{192}$ While the presence of a pledge executor and a pledge administrator still nominally constitute extra-judicial enforcement, they increase transactional costs and extend the time necessary to complete enforcement. Neither the Geneva Securities Convention nor UCC Article 9 contemplate a similar arrangement. By requiring the intervention of the pledge administrator and executor, the Mexican law, in seeking to ensure that the pledge is properly enforced, effectively discourages parties from using securities as collateral.

The logic for requiring the assistance of these two functionaries is rooted in the idea that the execution of a traditional pledge required assistance of an authority (e.g., notary or court) to ensure that the process of creation, perfection, and enforcement of pledges strictly complied with all legal requirements. Such concerns are no longer tenable and benefit only those who are authorized to act as pledge administrators and executors. These requirements do not benefit the two parties to a secured transaction and could be addressed through mechanisms available only in case of a dispute, rather than being applied across-the-board to all secured transactions. This uneconomic approach increases costs for all secured transactions. Furthermore, the concern regarding disposal of the collateral for an unreasonably low price is mitigated by the presence of a ready market for intermediated securities with publicly available price quotations.

While the pledged securities may be credited to the secured creditor's pledge account, in practice the parties select the pledge administrator's securities account to hold the pledged securities. Whenever the debtor defaults on a loan, the pledge administrator proceeds to quantify the amount owed under the secured obligation and communicates it to the pledge executor. ${ }^{193}$ Again, any concern that the secured creditor would inflate the amount of the owed obligation under this procedure can be mitigated by post-facto judicial verification.

\footnotetext{
$190 \mathrm{Id}$.

$191 \mathrm{Id}$.

192 See Financial Pledge Model Contract, supra note 168, at cl. 2.

193 Intermediation Agreement, supra note 100, at 17.
} 
These rules on enforcement involving third parties resemble those generally applicable to tangible assets under Mexican law. For instance, pursuant to Article 1414 bis of the Commercial Code, when the parties agree to the extra-judicial enforcement of a security interest covering equipment, they must also designate a third party that will appraise the value of the equipment after default and prior to its disposal. ${ }^{194}$

The subsequent steps required and identified herein also address any underlying anxieties of the debtor or third parties that the secured creditor might resort to unreasonable enforcement actions. Concurrently with quantifying the owed amount, the pledge administrator transfers the pledged securities to the securities account of the pledge executor. ${ }^{195}$ The pledge executor - through the debtor's brokerage house-proceeds to request payment from the debtor the same day it is notified that the default occurred. ${ }^{196}$ The debtor must be notified of this request directly by the debtor's brokerage house at the debtor's physical address designated in the intermediation agreement. ${ }^{197}$ Otherwise, the request must be notified through a notary public. ${ }^{198}$ Mexican law does not recognize any other alternative forms of communicating such requests (e.g., electronically), which complicates and delays their delivery. The payment request must also be notified to Indeval in order to alert it that an extra-judicial enforcement procedure has been initiated. ${ }^{199}$ Upon receipt of this notification, Indeval enables the pledge executor to dispose of the encumbered securities. ${ }^{200}$ The payment request must be in writing and must contain the following information: (1) identification of the secured obligation, (2) the outstanding amount, and (3) an indication that the encumbered securities will be sold if the secured obligation is not satisfied. ${ }^{201}$ The debtor has only one business day after the receipt of the notification to oppose the intended enforcement. ${ }^{202}$ While the time for the debtor to respond is extremely short, it is calculated from

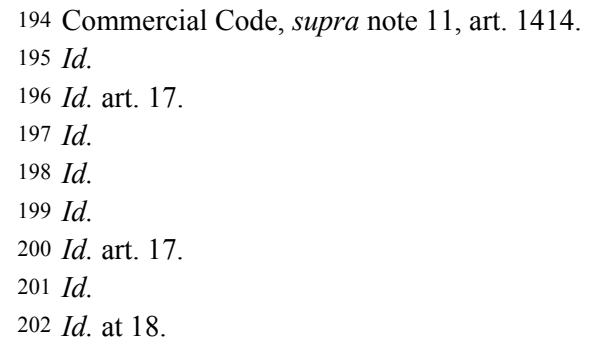


the time of delivery of the notification, which may be completed after a significant delay if the secured creditor must deliver that notification through a notary. The debtor can avert enforcement only by proving to the pledge executor that it has satisfied the secured obligation in full. ${ }^{203}$ On its face, this procedure resembles a quasi-judicial expedited process, which would be a preferable alternative to a typical judicial proceeding. However, any decision of the pledge executor is not final and the debtor may resort to the court. The possibility to appeal the pledge executor's decision makes the entire extra-judicial process an unnecessary administrative step that merely confirms what the secured creditor has already determined-i.e., that the debtor is in default. In the absence of full payment, the pledge executor will initiate the extrajudicial sale of the collateral on the securities exchange. ${ }^{204}$

The parties can also agree for the secured creditor to accept the encumbered securities in satisfaction of the secured obligation. ${ }^{205}$ This remedy was added only recently (in 2014) when the 2005 LMV was amended. After the default has occurred, the secured creditor is authorized to take ownership to encumbered securities that are sufficient to satisfy the secured obligation without having to go through the aforementioned procedure involving notifications, or through a judicial process. ${ }^{206}$ The effect of applying the collateral towards satisfaction of the secured obligation would be to extinguish the secured obligation up to the market price of the securities. ${ }^{207}$ This remedy does not involve a pledge administrator or executor, which saves time and makes it less costly for the parties. Accordingly, there no longer appears to be a concern with the secured creditor unreasonably quantifying the secured obligation or proceeding unreasonably against the securities, to justify the involvement of the two functionaries. This is a step in the right direction, and calls to question the logic and policy behind the retention of the formalities for enforcing financial pledges through disposal of the collateral. The introduction of this remedy into the Mexican legal framework might have effectively rendered the disposal remedy obsolete, since no reasonable creditor would be expected to incur the cost and delay of engaging the two functionaries.

\footnotetext{
203 Id.

204 Id.

2052005 LMV, supra note 10, art. 204.

206 Id.

207 Id.
} 
It should be noted that the parties to a financial pledge contract can establish the procedure for determining the market value of the encumbered securities, whether the securities are eventually taken in satisfaction of the obligation or disposed of. ${ }^{208}$ However, there is no requirement in the $2005 \mathrm{LMV}$ that the aforementioned procedure be commercially reasonable, raising apprehension particularly in connection with the remedy of accepting the collateral in satisfaction of the secured obligation. The concept of commercial reasonableness should underpin the entire enforcement process, and it is particularly critical in some of its aspects, such as valuation of securities. ${ }^{209}$

\section{VI}

\section{FINAL REMARKS}

Mexico's legal framework governing the intermediated holding of securities is based on the traditional principles of property, negotiable instruments, and certificated securities law that have been adapted to suit its needs. The objective of the drafters of the 2005 LMV was clearly limited to ensuring the validity and recognition of uncertificated securities and providing for their functional equivalence with certificated securities. Accordingly, the drafters restricted themselves to addressing a mechanical problem, rather than considering any practical and legal consequences of the intermediated holding model. ${ }^{210}$

No major event, such as insolvency of a securities intermediary, has really tested the system, but this may be largely because the market for securities held in Indeval is small and domestic, and not because the legal framework is modern, predictable, and dispute-preventive. As observed by many commentators, constructing a legal framework for an intermediated system based on the traditional notions of property law is problematic. ${ }^{211}$ As in many other countries, ${ }^{212}$ the Mexican legal framework for intermediated securities does not sufficiently eliminate the risks of market participants, therefore making it more costly and risky for financial institutions to consider participating in it. In one area,

\footnotetext{
208 Id.

209 LEGISLATIVE GuIDE, supra note 53, ๆ 287.

210 For a similar approach to the 1977 revision of UCC Article 8, see Aronstein, Haydock \& Scott, supra note 163, at 893.

211 Micheler, supra note 21, at 506; Charles W. Mooney, Jr., Beyond Negotiability: A New Model for Transfer and Pledge of Interests in Securities Controlled by Intermediaries, 12 CARDOZO L. REV. 305, 349-50 (1990).

212 Paech, supra note 21, at 1.
} 
the application of the traditional concepts is particularly problematic in Mexico.

Security interests in intermediated securities are expensive to execute, fraught with impractical requirements, ill-disposed to the ability or need of the debtor to retain access to the pledged securities, and burdened with formalities designed to protect debtors against the most remotely possible abusive conduct of secured creditors-all together having a paralyzing effect on the collateral value of securities. Additionally, the conflict of laws rules do not take into account the eventuality that securities accounts may hold securities immobilized with foreign CSDs, thereby raising costs by forcing secured creditors to comply with multiple laws when taking security interests. ${ }^{213}$ The area of securing obligations with intermediated securities is in acute need of reform, as the 2014 amendment introducing the appropriation remedy indicates that there are no coherent and consistent policy justifications for the credit-hindering rules for intermediated securities. Mexico should consider modernizing its legal framework according to the Geneva Securities Convention, as further elaborated on in the Legislative Guide. To address the inadequacy in the conflict of laws rules, Mexico should consider the ratification of the Hague Securities Convention or introduce law reforms to implement an approach based on the location of the relevant intermediary (PRIMA) as the main connecting factor. ${ }^{214}$ Presently, numerous laws govern different aspects of intermediated securities holding, thus increasing legal complexity. The attractiveness of the Mexican securities market should be enhanced by the promulgation of a comprehensive, stand-alone statute. ${ }^{215}$ Such a legislative effort should also consider the impact of emerging technologies, particularly blockchain, on the securities holding pattern as well as on the concepts embedded in the governing legal framework. Finally, any future reform effort should also touch on some aspects of intermediaries' insolvency, including efforts to enable the swift and efficient transfer of securities accounts of customers of an insolvent intermediary and the return of securities and cash balances to those customers. $^{216}$

213 Legislative GUIDE, supra note 53, 9294 (stating "adoption of the Convention or its incorporation into domestic law should therefore be accompanied by a set of clear and sound conflict of laws rules that reflect the reality of how securities are held and transferred").

214 Id. 9306.

215 Id. $\uparrow 323$.

216 Id. ๆๆ 263, 269, 274. 